\title{
GENTRIFICATION ON THE EXAMPLE OF SUBURBAN PARTS OF THE SZCZECIN URBAN AGGLOMERATION
}

\author{
Iwona Foryś, assoc. prof., PhD. \\ Department of Econometrics and Statisticsa \\ University of Szczecin \\ e-mail:forys@wneiz.pl
}

\begin{abstract}
Gentrification is a term first used by Ruth Glass in 1964 in reference to the process of taking over and revitalizing the degraded housing resources in the London Borough of Islington by their middle class owners. Ruth Glass discerned the impact of the improved living conditions in the gentrified area on ownership conditions, the appreciation of prices of land and houses, and changes in the social class structure. Nowadays, we can observe three types of changes taking place in gentrified parts of cities: economic, social and cultural ones.

The author of this article presents the evolution of gentrification and points out the advantages and threats brought about by this process, including its effect on urban space and real property prices. She identifies the gentrification processes in Poland and their social impact, and verifies the hypothesis that contemporary gentrification, apart from being a physical process, is above all, a social and cultural one. On the example of some parts of the Szczecin urban agglomeration, she shows that gentrification, extending into the suburbs and rural areas, results in irreversible changes in land use and social structure.
\end{abstract}

Keywords: gentrification, property value, real estate market.

JEL Classification: R58.

Citation: Foryś I., (2013), "Gentrification on the example of suburban parts of Szczecin urban agglomeration", Real Estate Management and Valuation, vol. 21, no. 3, pp. 5-14.

DOI: $10.2478 /$ remav-2013-0021.

\section{Introduction}

In Poland, gentrification is not a commonly recognized term, although for many years this process has been present throughout the country with varying intensity. This is because of the inter-disciplinary character of the process, which embraces the spatial, economic and social transformations that are the field of study of specialists dealing with various areas, such as land use management, urban studies, economics, sociology or culture. Moreover, there is a general reluctance to discuss gentrification processes due to their negative effects.

The transformation of the political system, especially the ownership transformation of the 1990s, created new investment opportunities for businesses operating on the real estate market. Investors' activity became no longer restricted solely to urban areas. On the contrary, they often extended their operation beyond the metropolitan limits, which resulted in irreversible urban sprawl. In addition to that and in contrast to the opinions of numerous researchers, gentrification turned out to be neither a short-lived nor narrow-ranged and insignificant process (BOURNE 1993).

Gentrified areas stretch over certain parts of Polish cities, suburban enclaves and newly urbanized rural areas. This is the first and foremost effect of urban sprawl, the consequence of years of unsatisfied housing demand as well as the changing housing preferences of individual investors. 
Thus, the gentrification process is interrelated with the real estate market. This interrelation is of a feedback nature: on the one hand, the gentrification processes are the reason for changes on the real estate market, while on the other hand, the latter determines gentrification trends.

The article discusses the subject of gentrification mainly, but not solely, in terms of its influence on the real estate market. The purpose of the paper is to point out the advantages and threats brought about by the gentrification process. These considerations will be preceded by the identification of gentrification processes in Poland and their social effects. The author will attempt to verify the hypothesis that contemporary gentrification, apart from being a physical process is, above all, a social and cultural one. She will also use the example of the Szczecin urban agglomeration (its selected parts) to verify the opinion that gentrification, covering suburbs and rural areas, results in irreversible changes in land use management as well as social structure.

\section{Gentrification in a Theoretical Approach}

\subsection{The Definition and Origins of Gentrification}

It was Ruth Glass who coined the term of gentrification in the early 1960s when describing the process of taking over and revitalizing the degraded housing resources in the London Borough of Islington by their middle class owners (HAMNETT, 2003). Apart from London, gentrification processes have been recognized and described at length in such cities as: Vancouver, Philadelphia, Washington, New York, Melbourne, Toronto, Sydney, Adelaide, Paris and Montreal. By the 1990s, gentrification processes and their analyses covered major cities on all the continents. When R. Glass was describing the process in London, she emphasized the improved condition of the housing resources influenced by gentrification, as well as altered ownership conditions, increased land and house prices and the changed social composition of the neighborhood. According to her, the physical betterment of living conditions occurred as a consequence of upgrading or demolishing old houses and the construction of modern ones, of better quality but also more expensive, in neighborhoods where working class residents used to live.

J. Grzeszczak was one of the researchers who reviewed the definitions of gentrification in Polish and international literature (GENTRYFIKACJA OSADNICTWA, 2010). According to the approach proposed in many publications, these definitions are divided into restrictive and inclusive ones. The former group contains the definitions in agreement with the original approach to gentrification, i.e., describing it as an invasion of areas from which poorer residents are being displaced by people from a higher social class (middle classes). Simultaneously to the residential shift, physical transformation takes place in the form of the renewal or demolition of degraded houses and the construction of modern buildings. Along with the new investments, ownership relations change, real estate prices rise, average household incomes increase and families with lower incomes are forced to move to other neighborhoods. The process of social displacement is the element which is most often emphasized in this classical approach to gentrification. The restrictive definitions also refer to the definition by C. Hammnett (Grzeszczak, 2010), according to whom gentrification "commonly involves the invasion by middle-class or higher-income groups of previously working-class neighborhoods ... and the replacement or displacement of many of the original occupants". Obviously, the inflow of a new social group results in (or from) adjusting the housing resources to the needs of new residents, while the emergence of high quality housing translates to the appreciation of real estate prices. The above mentioned approach to gentrification was extended by A. Warde, who distinguished four elements of this process (Grzeszczak, 2010):

- migration and concentration of higher status groups resulting from the displacement of residents of a lower social status,

- transformation of the developed areas and emergence of new facilities which satisfy the new residents' demand for services,

- concentration of people who have similar consumer preferences,

- reappraisal of real estate resources.

The concentration of new residents coming from a higher social class and having similar consumer preferences, both in terms of basic as well as higher order goods, in one neighborhood generates the demand for a new type of services that have not been previously available in the gentrified area. The need for new services in turn gives rise to the demand for new business space and infrastructure, 
which usually accompany residential areas of higher standard. Consequently, property characterized by functions other than residential becomes more expensive as well.

The inclusive approach to gentrification focuses on:

- the transformation of neighborhoods whose residents come from the middle and upper class,

- the transformation of the function of the area from non-residential to residential,

- the development of previously undeveloped areas.

The change in function usually refer to the change of industrial sites to residential developments (e.g., lofts), i.e., converting old and abandoned office or industrial buildings, warehouses, harbor facilities or public utility buildings into state-of-the-art exclusive flats. The development of previously undeveloped land is described as residentialization and is typical of the third wave of the gentrification process. It means that gated and guarded residential developments are isolated from the public area and sold to high-income and high-status families. In the case of residentialization, the displacement of lower-income residents is not its most characteristic feature, which obviously takes place but not on such a vast scale as in gentrified inner-city districts. We can say that it is rather the process of high-income classes isolating themselves from poorer neighbors, which in the first phase of gentrification can be associated with forcing out the latter by the extensive takeover of development land. It seems that the most appropriate conceptualization of this process is the definition proposed by E. Clark (CLARK, 2005) who emphasizes the replacement of a population with lower social and economic status with new richer residents.

Contemporary gentrification is more focused on the final effects of the process than on its historical or geographical aspects (GRZESZCZAK, 2010), taking into consideration:

- the reinvestment of capital,

- the role that new high-income residents are playing in improving the local community's social level,

- the changes in the local landscape (streetscape),

- the displacement of low-income groups.

Today we can observe three types of changes taking place in gentrified neighborhoods: economic, social and cultural ones. Economic gentrification refers to the change of the economic status of local residents and higher costs of living, accompanied by growing real estate prices. Social gentrification means the change in the social composition of an area, which in turn leads to cultural gentrification, i.e., the change of the gentrifiers' habits and expectations and, in consequence, to converting the neighborhood into a more prestigious one. Each of the above elements has an effect on land use management and thus, on the local landscape (streetscape).

In other studies on gentrification, some authors are rather skeptical about the geographical scope and scale of the phenomenon. Although initially gentrification was regarded as a short-lived (BERRY, 1980), temporary (LEY, 1992) and limited process, it has matured and is becoming more and more complex. Both the course of gentrification and the participation of businesses, and thus the process effects, vary geographically. Also, the course of the process is closely linked to the situation on the real estate market and of the local economy. More and more often, globalization is regarded as responsible for the direction and intensity of gentrification processes (ROFE, 2003). Globalization is a manifestation of a wide variety of changes in social, cultural, political and economic structures, which leads us to seek its relationships with gentrification.

Based on American studies, researchers dealing with gentrification have distinguished four phases of the process (GRZESZCZAK, 2010):

- occasional gentrification (before 1973),

- anchoring of gentrification (1978-1988),

- common (third wave) gentrification (1989-2000),

- super-gentrification (since 2001).

The first phase of gentrification was a period when the process was not common, even though it was present in large cities all over the world. Here, the significant role of governmental institutions in triggering gentrification processes is emphasized. In the second phase, their role had been weakened by market mechanisms, while what is characteristic of the third phase is that the process expanded into the suburbs and covered different forms of developed areas. Today, gentrification refers to the same space that had been gentrified before, with the difference being that nowadays, the process 
involves global capital markets. Governmental institutions have regained their previously abandoned position by including gentrification into their social and land use policies.

\subsection{Gentrification and Revitalization}

Gentrification has become a method of describing and explaining the changes occurring in urban social and spatial structures (WĘCEAWOWICZ, 2007). The scope of this term as well as the number of its definitions have led to a situation where other processes of reshaping degraded urban space are treated as an element of gentrification or, on the contrary, gentrification is regarded as a part of processes such as reurbanization or revitalization. Each of the three above mentioned terms does not have one generally acknowledged definition which would allow for an unambiguous description of their mutual relations. What is more, the opinions of other authors on this matter are often contradictory.

According to A. Haase, reurbanization and gentrification differ as far as their subject of reference is concerned (GRZESZCZAK, 2010). Reurbanization refers to a broader process, including different groups of residents, which in the context of such a vast study of social inequality is not the core subject of studies on gentrification. According to such an approach, gentrification is a part of reurbanization, although in concepts where the scope of reurbanization is narrow, these two processes are treated as one.

Similarly, the comparison of gentrification and revitalization does not clarify the difference between these two processes. In the opinion of some authors, gentrification, which refers to changes in morphological and socio-economic structures, is a broader process than revitalization. Others (e.g., N. CARMON, A. LISOWSKI) insist that gentrification is the initial stage of revitalization and that these two processes cannot be separated (GRZESZCZAK, 2010). G. Węcłowicz points out that the term "gentrification" gradually replaced the term "revitalization" of problem areas in inner cities, especially in the first half of the 20th century. On the other hand, the process of gradually taking over a part of the local authorities' responsibilities concerning the urban renovation process by local residents and private investors (i.e., gentrification) has become a part of a broader program, i.e., revitalization. In Poland, revitalization is said to follow gentrification processes (WĘCŁOWICZ, 2007).

If we adopt the definition that revitalization is an intentional, planned and coordinated process aimed at the reversal of negative trends taking place in urban problem areas while attributing spontaneity to gentrification, we can agree with A.Jadach-Sepiło who states that "revitalization is an institutionally supported process of revival, while gentrification is a market process of revival" (GRZESZCZAK, 2010). Thus, revitalization is an intentional policy of local authorities, while gentrification falls outside of any local government programs.

\section{Gentrification on the Example of Selected Neighbourhoods in the Szczecin Urban Agglomeration}

\subsection{Gentrification or Revitalisation of Neighbourhoods in Szczecin?}

In the preceding chapter, the author explained the notion of gentrification in different phases of development. The signs of gentrification that has been taking place in the urban agglomeration of Szczecin are typical of each of the three phases, depending on the areas in which they have occurred. The characteristic feature of the first phase was the extensive participation of government institutions in triggering gentrification processes. As had been mentioned before, this is characteristic of the revitalization processes which, according to local revitalization programs, cover the inner city, port neighborhoods in the north of Szczecin and the centre of the Dąbie district. These are areas of multitenant, mostly council housing, parts of which have been bought out by residents and managed by companies where the gmina is a majority holder, such as STBS, TBS Prawobrzeże or SCR. The idea behind these projects is the revival of degraded and recapitalized housing resources, changes in urban arrangement and social replacement in the revitalized districts. One of such districts lies in the heart of Szczecin and covers several blocks of houses. This part of the city should play a representative function, but instead contains derelict and under-invested housing resources, the architectural value of which remains untapped. A complex of several dozen blocks of tenement houses built in the second half of the $19^{\text {th }}$ century and in the early $20^{\text {th }}$ century has become what is now the inner city. Apart from being a venue of many urban functions, its principal function is housing. The area was neglected for decades and today the technical condition of many of its buildings is still far from perfect. Therefore, since the early 1990s, city development projects have included their renovation. 
Today, we can observe that the material status of tenants residing in the renovated buildings is much higher than before. Companies that manage these blocks have successfully changed the social composition of this neighborhood by resettling the former residents to buildings constructed by TBS (the Social Housing Association) in other parts of the city. Residential and non-residential properties were sold to new tenants at the market price, so the previous residents could not afford them. In the non-residential premises, new businesses, such as restaurants, boutiques or services that had been absent in the area before, e.g., lawyer's offices, soon appeared. The neighborhood saw all the effects typical of the gentrification process, i.e., the displacement of low-income residents, reshaping the urban fabric through upgrading or demolition and the growth of property prices. However, the gentrification process was not triggered by market mechanisms but, on the contrary, the changes had been initiated and created by local government institutions. Their intervention concerned both the organizational part of the process (i.e., the establishment of council-owned companies where the real estate in question was an in-kind contribution) as well as financing the transformation (credit guarantees by gminas, support programs for revitalization initiatives). What is more, the local government interventionism included legal regulations, such as changes to local land use plans. The decreasing role of the above institutions is typical of the second phase of gentrification.

A planning tool is an instrument which supports gentrification mechanisms typical of the third wave of gentrification, i.e., the conversion of non-residential areas, including industrial wastelands (abandoned harbor facilities or premises of closed down state-owned companies) and undeveloped land. City development trends and respective land use plans adopted for those areas which, according to local councils, should change their character, aim to intentionally shift individual investors' potential to these areas. If this process is additionally correlated with easier access to funds in the form of subsidized loans or tax deductions, then only better-off residents can settle in the new area, which consequently leads to economic segregation and to adjusting the newly developed space to the needs and expectations of high-income households.

\subsection{Gentrification in the Selected Gminas of the Szczecin Urban Agglomeration}

A distinctive feature of the third wave of gentrification is the expansion of the process to include suburban areas. This trend and its effects will be shown on the example of two gminas located on the border of the Szczecin city limits.

Dobra and Kołbaskowo Gminas (communes) are rural communities located in the poviat (district) of Police, respectively to the north-west and south-west of Szczecin (Figure 1). Their growth was not in keeping with the development strategy adopted for Szczecin, which assumed that the city would grow along the north-south axis, following the Odra river and its tributaries. The western sprawl of the city over the above mentioned two gminas brought about many negative effects for Szczecin.

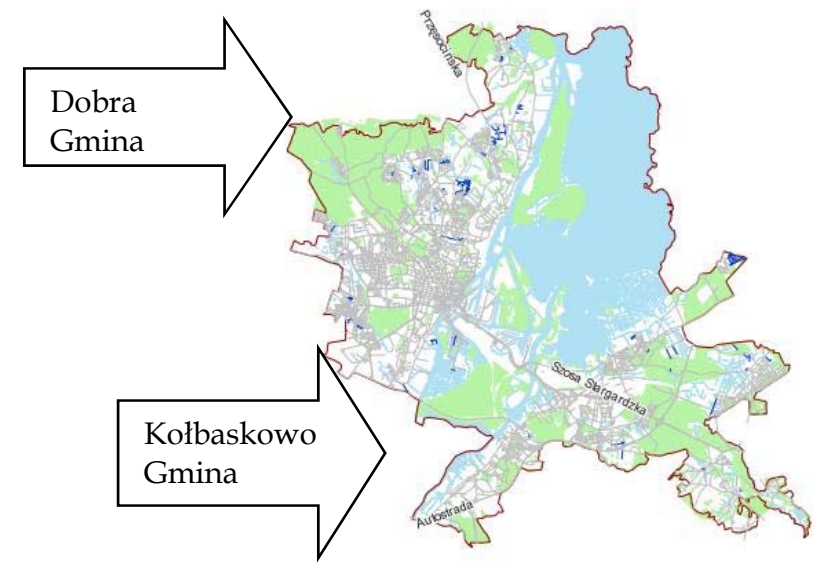

(2500 n

Fig. 1. Geographical position of Dobra and Kołbaskowo gminas located near Szczecin. Source: http://gis.um.szczecin.pl/UMSzczecinGIS/chapter_85000.asp.

Dobra Gmina includes the gmina village of Dobra and its seven village councils: Bezrzecze, Buk, Dołuje, Grzepnica, Łęgi, Mierzyn, and Rzędziny, the villages and settlements of Kościno, Lubieszyn, 
Płochocin, Redlica, and Sławoszewo as well as two abandoned villages of Linki and Rybocin. The gmina borders the poviat of Police, the urban poviat of Szczecin and the German district of UeckerRandow. It is situated on the Wzniesienia Szczecińskie - Wał Stobniański (Szczecin Hills) and in Puszcza Wkrzańska (the Wkrzańska Forest), and is the home of the Świdwie nature reserve. Forests cover $22 \%$ of its area, with agricultural land accounting for $63 \%$. Until 1990, the gmina was scarcely populated and, due to the low quality of the local soil, farming production was low. Because of its location at the national border, the area was not intensely urbanised. National road No. 10, which runs through the gmina, links the Polish-German border crossing with Szczecin.

Kołbaskowo Gmina consists of the gmina village Kołbaskowo and fifteen village councils, four settlements and villages, as well as four abandoned settlements and villages. The gmina borders the gminas of Dobra and Szczecin, the poviat of Gryfino and two German districts of MecklemburgVorpommern and Brandenburg. It is situated on Wzniesienia Szczecińskie - Wał Bezleśny and in Dolina Dolnej Odry (the Lower Odra Valley). The region of Międzyodrze (the area between the branches of the Odra River) covers the nature park of Dolina Dolnej Odry with its three nature reserves: Kurowskie Błota, Kanał Kwiatowy and Wzgórze Widokowe nad Międzyodrzem. There is a pedestrian border crossing in Bobolin. Forests cover $7 \%$ and farmland $-67 \%$ of the gmina. Despite many investments, local residents continue to be involved in agricultural production.

After 1990, both gminas became attractive places for private investors. Firstly, the gminas experienced an expansion of individual housing investments. In the subsequent years, due to a bad land use policy in Szczecin which put forth restrictions on investments in the city, there was an investment boom in both gminas in terms of single-family and multi-family housing. As a result, some villages in Dobra Gmina turned into housing estates, often merging with the fringe districts of Szczecin. The village of Bezrzecze overlaps, especially functionally, the part of Szczecin that goes by the same name.

The growth was the effect of neither the city land use policy nor infrastructural investments in the city (such as roads). On the contrary, urban development had been planned on the north-south axis rather than in the suburban areas to the west of Szczecin. In the initial phase, the main incentive to invest in the above gminas was the price of land which was cheaper than in the city itself. In the subsequent phases of urban sprawl, these prices rose reaching those paid for lots in the most attractive parts of Szczecin.

The inflow of residential investments forced out traditional settlement developments that were often connected with farming and replaced them with typical urban functions. The original residents, who were used to a country lifestyle, started moving to villages located further away from the city limits. In both cases, the process of gentrification led to the invasion of high-income residents. The economic effects of gentrification can be identified by analyzing the derivatives of the population's income. Personal income tax and corporate income tax, which are levied by the national budget and are the gminas' own revenue, can serve as appropriate measures of this. In the latter case, this information is crucial when there is a high share of physical persons running businesses registered in the given gmina.

At the end of the first quarter of 2012, there were 2,721 physical persons who ran businesses in the Dobra Gmina in relation to 3,215 registered economic entities, while in Kołbaskowo Gmina, the proportion was, respectively, 1,286 to 1,584 , which gives an $84.6 \%$ share of physical persons in the first gmina and a $81.2 \%$ in the latter. Therefore, contrary to personal income tax, corporate income tax is not a good parameter of the residents' economic status in both of the analyzed gminas.

Table 1 shows the structure of the gmina's own revenue in Dobra during the period of 2000-2011 in four groups of revenue: personal income tax, corporate income tax, property tax and civil law transactions tax. The latter two can provide reliable, although imperfect, characteristics of changes on the real estate market.

In the period of 2000-2011 the Dobra Gmina experienced growing revenue from personal and corporate income taxes. In 2000, the gmina collected PLN 2,127,000 from personal income tax and PLN 97,000 from corporate income tax. In 2001, the levy rose respectively to: PLN 21,803,000 and PLN 294,300 , i.e., ten times more in the case of PIT and three times more in the case of CIT. In the period of 2000-2011, property tax revenue rose more than threefold, which was the result of market growth.

The gmina revenue from the tax on civil law transactions increased until 2007, after which it started to decline annually. However, in 2011 it was still twice as high as in 2004, which means that at times of real estate market decline, properties maintained their high prices. We should also note the 
significant and growing share of personal income tax in the gmina revenue, which in 2011 reached $60 \%$.

Table 1

Changes in the revenue structure of Dobra Gmina in 2000-2011

\begin{tabular}{ccccc}
\hline Year & $\begin{array}{c}\text { Proportion of taxes in } \\
\text { the gmina budget } \\
\text { revenue - personal } \\
\text { income tax (\%) }\end{array}$ & $\begin{array}{c}\text { Proportion of taxes in } \\
\text { the gmina budget } \\
\text { revenue - corporate } \\
\text { income tax }(\%)\end{array}$ & $\begin{array}{c}\text { Proportion of taxes in } \\
\text { the gmina revenue }- \\
\text { property tax }(\%)\end{array}$ & $\begin{array}{c}\text { Proportion of taxes in } \\
\text { the gmina revenue - tax } \\
\text { on civil law transactions } \\
(\%)\end{array}$ \\
\hline 2000 & 19.7 & 0.9 & 21.3 & \\
\hline 2001 & 26.7 & 1.1 & 24.8 & \\
\hline 2002 & 29.0 & 0.9 & 29.9 & 8.6 \\
\hline 2003 & 30.6 & 2.0 & 32.3 & 7.4 \\
\hline 2004 & 37.6 & 3.0 & 27.3 & 8.2 \\
\hline 2005 & 41.9 & 3.2 & 25.3 & 12.8 \\
\hline 2006 & 36.6 & 2.7 & 19.1 & 11.2 \\
\hline 2007 & 44.4 & 2.9 & 20.1 & 6.1 \\
\hline 2008 & 48.7 & 3.1 & 19.7 & 6.6 \\
\hline 2009 & 57.5 & 0.4 & 21.8 & 2.4 \\
\hline 2010 & 54.8 & 0.4 & 20.9 & \\
\hline 2011 & 59.5 & 0.8 & 21.5 & \\
\hline
\end{tabular}

Source: own study on the basis of the Province Statistical Office in Szczecin.

Table 2 shows the structure of the gmina's own revenue in Kołbaskowo over the period of 20002011. In that particular gmina, the revenue from personal income tax grew almost sixfold in the analyzed time span (from PLN 1,406,000 in 2000 to PLN 8,132,800 in 2011), with revenue from corporate income tax increasing almost fourfold. Entrepreneurship in Kołbaskowo Gmina is much better established than in Dobra Gmina. Companies that are based there deal with both trade and services. Over the 2000-2011 period, gmina revenue from property tax increased more than threefold, with revenue from the tax on civil law transactions almost doubling in the years 2004-2011. Similarly to the Dobra Gmina, the share of personal income tax in Kołbaskowo in the gmina's own revenue has been increasing from year to year, though remaining much less significant at 38.5\% in 2011.

Table 2

Changes in the revenue structure of Kołbaskowo Gmina in 2000-2010

\begin{tabular}{ccccc}
\hline Year & $\begin{array}{c}\text { Proportion of taxes in } \\
\text { the gmina budget } \\
\text { revenue - personal } \\
\text { income tax } \\
(\%)\end{array}$ & $\begin{array}{c}\text { Proportion of taxes in } \\
\text { the gmina budget } \\
\text { revenue - corporate } \\
\text { income tax } \\
(\%)\end{array}$ & $\begin{array}{c}\text { Proportion of taxes the } \\
\text { gmina revenue }- \\
\text { property tax } \\
(\%)\end{array}$ & $\begin{array}{c}\text { Proportion of taxes the } \\
\text { gmina revenue - tax on } \\
\text { civil law transactions } \\
(\%)\end{array}$ \\
\hline 2000 & 16.9 & 0.7 & 29.8 & \\
\hline 2001 & 19.0 & 0.5 & 37.7 & \\
\hline 2002 & 17.5 & 1.6 & 44.1 & 5.3 \\
\hline 2003 & 22.5 & 1.2 & 39.3 & 3.7 \\
\hline 2004 & 29.8 & 2.0 & 42.5 & 12.8 \\
\hline 2005 & 29.1 & 1.9 & 36.5 & 7.3 \\
\hline 2006 & 36.8 & 3.9 & 36.1 & 3.8 \\
\hline 2007 & 36.5 & 3.4 & 32.2 & 4.7 \\
\hline 2008 & 38.8 & 2.8 & 28.9 & 4.1 \\
\hline 2009 & 39.1 & 2.0 & 34.9 & 32.5 \\
\hline 2010 & 33.0 & 2.5 & 37.3 & \\
\hline 2011 & 38.5 & 1.0 & & \\
\hline
\end{tabular}

Source: own study.

In order to prove the impact of the gentrification process on the local real estate market, the author 
analyzed the changes in real estate prices in the chosen gminas in 2009-2011, i.e., in the time of the economic crisis when downward trends on the real estate markets were common. The average transaction prices were determined on the basis of a database of transaction details taken from notarial deeds and containing all the real estate transactions concluded in the analyzed period. Table 3 shows examples of changes in the average prices of single-family houses, as well as the unit prices of residential development lots and flats in multi-tenant buildings in the gmina of Dobra in 2009-2011.

Table 3

Price changes on the real estate market in Dobra Gmina in 2009-2011

\begin{tabular}{cccc}
\hline Year & $\begin{array}{c}\text { Average house price } \\
(\text { PLN) }\end{array}$ & $\begin{array}{c}\text { Average price of a } \\
\text { residential development } \\
\text { lot } \\
\left(\text { PLN/m } / \mathrm{m}^{2}\right)\end{array}$ & $\begin{array}{c}\text { Average flat price } \\
(\text { PLN/m })\end{array}$ \\
\hline 2009 & 530990 & 170 & 4511 \\
\hline 2010 & 543419 & 178 & 4683 \\
\hline 2011 & 631818 & 185 & 4660 \\
\hline $2009-2011$ & $19 \%$ & $8.8 \%$ & $3.3 \%$ \\
\hline
\end{tabular}

Source: own study on the basis of notarial deeds.

Even though the prices of properties in the Szczecin urban agglomeration fell during the analyzed time period (Foryś, 2012), which was the effect of the 2008 economic crisis and the slump on the real estate market, Dobra Gmina saw a rise in the average (median) prices of all three of the above mentioned types of property. Over the three years, the highest increase of $19 \%$ was recorded in the case of the median price of single-family houses, which were the most popular form of investment in the gmina. The slowest growth was observed in the transaction prices of flats in multi-tenant buildings, which could be the effect of both the market decline and the oversupply of new flats offered by developers.

Gentrification brings about changes in the urban space and landscape. In the analyzed gminas, it has altered the morphological structure of villages that have lost their rural character and gained new, urban functions. Dynamic migration from cities and the residential development of rural areas resulted in the demand for a new road infrastructure, utilities, parking lots or education facilities. Two new schools are being built in the Dobra Gmina and new kindergartens have opened. The villages have become more similar to city housing developments, with multi-tenant housing and its typical infrastructure. These often take the form of fenced-in estates. Over-development is colonizing the green areas and its character varies from that of traditional suburban architecture, which is partially the result of the high prices of building lots. All of this leads to significant changes in the landscape of the gentrified area.

\section{Social Effects of Gentrification in the Selected Gminas of the Szczecin Urban Agglomeration}

The negative aspects of gentrification result from spatial segregation and social exclusion in the gentrified areas. In Poland, the main players in this process are high-income households (who are first to initiate the suburbanization processes) and medium-income ones (who contribute to urban sprawl), while people who search for unconventional places of residence (active participants of revitalization) do not play a significant role. When making the decision to settle down in new areas and thus, forcing out their original residents, each of the above mentioned groups contributes to disruption in the local demography, which leads to changes in the population composition in terms of the people's economic status and social position, as well as the age structure of the local population. What is more, the new residents' professional and household structure is different, which is strictly connected with the demographic changes.

Figure 2 presents the dynamics of demographic changes in Dobra and Kołbaskowo Gminas. These population dynamics and migrations within the urban agglomeration of Szczecin clearly show how fast population growth in rural areas occurs, to the disadvantage of the city population. This trend, however, has not been followed by changes in the gentrifiers' lifestyles.

In 2011, the population of Dobra Gmina doubled in comparison to 2001, despite the general downward trend of birth rates noted elsewhere. The rate of this process was slower in Kołbaskowo 
Gmina, where the population grew by $30 \%$ during the same period, which also goes against the demographic trends observed in other gminas of this urban agglomeration.

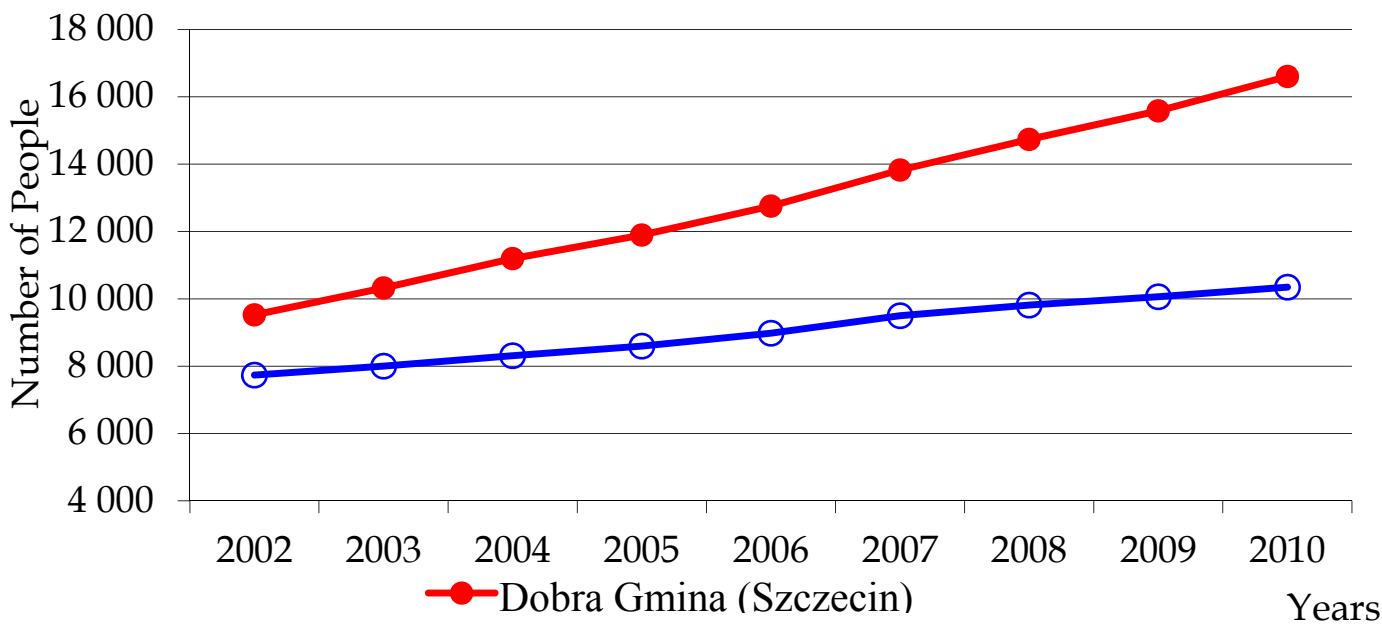

Fig. 2. The population dynamics in Dobra and Kołbaskowo Gminas near Szczecin, Source: own study.

A new social composition of the gentrified area means that the new residents' system of values, their lifestyles and habits differ from the local ones, which continue to remain typical of village life. Gentrifiers have higher needs for culture, education and leisure services than ones that had been offered in the local community before. What is more, in the analyzed gminas, the locals have neither improved their quality of life nor assimilated with the new neighbors, while the money they got from the sale of their land has not led to changes in their lifestyles.

As a consequence, we can observe both positive and negative effects of the displacement of previous residents in the gentrified areas. The positive effects undoubtedly include the economic results of gentrification, in particular:

- increased real estate value,

- revival of the degraded inner-city,

- physical renewal of buildings in the gentrified areas,

- fewer uninhabited flats or buildings,

- more fiscal income,

- economic and cultural recovery,

- improved development perspectives for the gentrified areas,

- reduced urban sprawl,

which directly or indirectly translate into social effects, such as a transformed social structure and larger share of high-income residents in the neighborhood, which in turn results in reduced crime.

The negative side of gentrification includes such economic effects as:

- speculative growth of real estate prices in the first gentrification phase,

- decreased availability of housing resources,

- a significant increase in the prices of local services,

- economic polarization,

which lead to numerous adverse social effects. Higher property prices or rents contribute to more evictions or homelessness for economic reasons, especially in the urban areas. What is more, there are the psychological costs of evictions or displacement in the areas stricken by the external effects of gentrification, i.e., affected by the pressure of demand on the local real estate market. Over time, a disturbed social balance has been observed in the districts neighboring the gentrified parts of a city.

Furthermore, the demand for some jobs, especially in services satisfying lower-level needs and in industry, disappears in the gentrified areas. All this leads to higher unemployment rates, less tolerance and, consequently, social conflicts in the local communities. Also worth considering is the fact that gentrifiers tend to take over positions of power in their communities, which is preceded by lobbying for the sake of the new residents' needs or by pressure put on local decision-makers concerning public spending. The new social groups are more active, better skilled and better educated. They therefore colonize the public sphere as well. 


\section{Summary and Conclusions}

The gentrification process described above has been observed over the last two decades in Poland, both in urban agglomerations and in rural areas. Although gentrification is not associated with racial segregation in Poland, it still leads to geographical and economic segregation, i.e., to social exclusion. All over the country as well as in the two above analyzed gminas of the Szczecin urban agglomeration, the signs of gentrification are evident. These signs include:

- demographic changes divergent from general trends,

- increased revenue of local governments,

- speculative growth of real estate prices,

- higher outlays on new cultural, educational and leisure infrastructure,

in the gentrified areas.

Polish gentrification trends appear both in the industrial wastelands of cities (revitalization) and in their suburbs, in the neighboring rural areas (suburbanization). In Poland we can witness, first of all, the revitalization of degraded neighborhoods or the speculative growth of real estate prices, which is additionally disturbed by a deep fluctuation of the real estate market cycle.

The advantage of gentrification in Poland is the improved social structure in the gentrified areas and the fact that the process is stimulated by private development companies operating independently of public institutions. We can say that gentrification is poorly controlled by Polish local governments and the absence of local policies concerning new land use trends and urban functions makes this process even stronger. The disadvantages of gentrification in Poland (as it has been shown on the example of the analyzed gminas) include inefficient communal infrastructure in the gentrified areas, adapting social structure to the physical structure of local resources, displacing low-income residents to areas of cheap housing and, finally, creating new poor neighborhoods.

Similarly to the analyzed gminas and districts in the Szczecin urban agglomeration, the effects of gentrification are most evidently manifested by the demographic changes in gminas neighboring big cities as well as by the rapid increase of property prices. The latter could be analyzed on the basis of revenue from the tax on property value which, unfortunately, has not yet been introduced in Poland. The above mentioned effects of gentrification translate to changes in city landscapes. In Szczecin, gentrification has taken the form of both residentialization and the fourth phase of the process. The social effects of gentrification include a change in lifestyles (new leisure, shopping or education facilities), pushing local residents out of public life along with their displacement and growing social segregation in the gentrified neighborhoods.

Gentrification is a process which is advantageous to socially unprivileged areas since it offers development opportunities to the local population. However, when it goes too far and occurs too fast, it leads to local residents being forced out of the gentrified areas or to a form of ghettos being formed for those who have become socially excluded as a result of the process.

\section{Bibliography}

BERRY B.J.L., 1980, Inner city futures: an American dilemma revisited, Transactions of the Institute of British Geographers, Vol. 5, No 1, pp. 1-28.

BOURNE L.S., 1993, The demise of gentrification? A commentary and prospective view, Urban Geography, Vol. 14, Issue 1, pp. 95-107.

CLARK E.,1995, “The rent gap re-examined, Urban Studies, Vol. 32, Issue 4, pp. 1489-1503.

FORYŚ I., 2012, Analiza cen transakcyjnych na szczecińskim rynku nieruchomości, Rzeczoznawca Majątkowy Vol. 74, Issue 2, pp. 18-25.

GrZeszCZAK J., 2010, Gospodarka przestrzenna. Podstawy teoretyczne, Wydawnictwo Naukowe PWN, Warszawa.

HAMNETT, 2003, A Gentrification, Postindustrialism, and Industrial and Occupational Restructuring in Global Cities, w: Companion to the City, red. Bridge G., Watson S., Blackwell Publishing Company.

LEY D., 1992, Gentrification in recession: social change in six Canadian inner cities, 1981-1986, Urban Geography, Vol. 13, Issue 3, pp. 230-256.

ROFE M.W., 2003, "J want to be global": theorizing the gentrifying class as an emergent elite global community, Urban Studies, Vol. 40, Issue 12, pp. 2511-2526.

WĘCŁAWOWICZ G., 2007, Geografia spoteczna miast, Wydawnictwo Naukowe PWN, Warszawa. 